\title{
Correlating tropospheric column ozone with tropopause folds: the Aura-OMI satellite data
}

\author{
Q. Tang and M. J. Prather \\ Department of Earth System Science, University of California, Irvine, California, 92697, USA \\ Received: 4 May 2010 - Published in Atmos. Chem. Phys. Discuss.: 16 June 2010 \\ Revised: 29 August 2010 - Accepted: 20 September 2010 - Published: 12 October 2010
}

\begin{abstract}
The geographic and temporal variations in tropospheric and stratospheric ozone columns from individual swath measurements of the Ozone Monitoring Instrument (OMI), on the NASA Aura spacecraft, are reasonably well simulated by the University of California, Irvine (UCI) chemistry transport model $(\mathrm{CTM})$ using $1^{\circ} \times 1^{\circ} \times 40$ layer meteorological fields for the year 2005. From the CTM we find that high-frequency spatial variations in tropospheric column ozone (TCO), including around the jet streams, are not generally correlated with variations in stratospheric ozone column, but instead are collocated with folding events involving stratospheric-origin, high-ozone layers below the tropopause. The CTM fold events are verified in many cases with available ozone sondes. Using the OMI Level 2 profiles, and defining tropopause height from our CTM using the European Centre for Medium-Range Weather Forecasts (ECMWF) fields, we find that most of the variations in TCO near CTM folding events are also not correlated with those in stratospheric ozone column. A large fraction of the OMI TCO variance is accurately simulated by the CTM where the variance is significant, especially along the subtropical jets. The absolute tropospheric columns from OMI and CTM agree swath-by-swath, pixel-by-pixel within \pm 5 Dobson Units (DU) for most cases. Notable exceptions are in the tropics where neither the high ozone from biomass burning nor the low ozone in the convergence zones over the Pacific is found in the OMI observations, because of OMI's insensitivity to the lower troposphere. Another difference is identified with the OMI profiles near the southern subtropical jet. The CTM has a high bias in stratospheric column outside the tropics, due to problems previously identified with
\end{abstract}

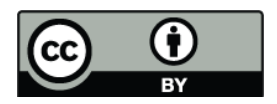

Correspondence to: Q. Tang (tangq@uci.edu) the stratospheric circulation in the 40-layer meteorological fields. Overall, we identify ozone folds with short-lived features in TCO that have scales of a few hundred kilometres as observed by OMI.

\section{Introduction}

Stratosphere-troposphere exchange (STE) plays an important role in determining the chemical composition in the atmosphere, bringing $\mathrm{O}_{3}$-rich stratospheric air into the troposphere (Danielsen, 1968), affecting the oxidative capacity of the atmosphere (Levy, 1972; Crutzen, 1973). Many studies have aimed at quantifying the STE flux (e.g., Danielsen, 1968; Holton et al., 1995; Appenzeller et al., 1996; Olsen et al., 2003; Sprenger et al., 2003; Stohl et al., 2003; Jaeger and Sprenger, 2009). This is a global problem that requires global observation and modelling. We identify $\mathrm{STE} \mathrm{O}_{3}$ flux with many tropopause folds (TF) in our chemistry transport model (CTM) and then show that these folds are observed as variations in tropospheric column ozone (TCO) on a daily global basis by the Aura Ozone Monitoring Instrument (OMI) satellite measurement.

Tropopause folding in the vicinity of both subtropical and polar jets have been observed to be a particularly important process leading to STE (e.g., Danielsen, 1968; Lamarque and Hess, 1994; Beekmann et al., 1997; Baray et al., 2000; Traub and Lelieveld, 2003). TFs facilitate a great amount of STE flux, although not all of the material in the folds enters the troposphere (Hsu et al., 2005). We have looked for evidence of TF in the four Aura ozone instruments. In our model and ozone sonde data most folds are about $1-2 \mathrm{~km}$ thick and occur between 150-300 hPa. The Microwave Limb Sounder (MLS) with only three levels below $100 \mathrm{hPa}$ is unable to

Published by Copernicus Publications on behalf of the European Geosciences Union. 
resolve most folds. The High Resolution Dynamics Limb Sounder (HIRDLS) with higher vertical resolution still does not have enough useful data below $150 \mathrm{hPa}$. We are left with identifying TF in the tropospheric data from the Tropospheric Emission Spectrometer (TES) and OMI. Neither instruments, however, can resolve most folds vertically and, thus, identification requires matching geographic anomaly patterns in the tropospheric columns. The wide swath data from OMI is our first choice and is analysed here.

First, we evaluate the CTM using ozone sonde data, finding good agreement for the 638 exact matches between $35^{\circ} \mathrm{S}$ and $40^{\circ} \mathrm{N}$ in the year 2005. The criteria of detecting TF in the CTM are described at the end of Sect. 2. Good consistency between the OMI and CTM TCO and total ozone is shown in Sect. 3. In Sect. 3.1, we find TFs are correlated with anomalies in TCO but not in total ozone. Furthermore, we try to link TCO anomalies with STE $\mathrm{O}_{3}$ flux in Sect. 4 and find good correlation in the vicinity of subtropical jets, but not in high latitudes.

\section{Chemistry transport model and ozone sondes}

The chemistry transport model (CTM) is driven by piecedtogether, spun-up forecasts from the Integrated Forecast System of the European Centre for Medium-Range Weather Forecasts (ECMWF) developed in collaboration with University of Oslo. The CTM is run at $1^{\circ} \times 1^{\circ} \times 40$-layer spatial resolution with $\sim 1 \mathrm{~km}$ vertical resolution near the tropopause. The uppermost layer is exceedingly coarse (2$22 \mathrm{hPa}$ ). The chemistry scheme is a combination of the ASAD software package for the troposphere (Carver et al., 1997; Wild et al., 2003) and linearized ozone scheme for the stratosphere (Linoz version 2) (Hsu and Prather, 2009). The ASAD algorithm has been recently rewritten at UCI, including the steady-state assumptions used to optimize the solver. We use the Year-2000 emissions from the EU Quantifying the Climate Impact of Global and European Transport Systems (QUANTIFY) project, with monthly biomass burning emissions from the average multi-year (1997-2002) Global Fire Emissions Database (Hoor et al., 2009). Lightning $\mathrm{NO}_{\mathrm{x}}\left(\mathrm{NO}+\mathrm{NO}_{2}\right)$ is scaled linearly to the deep convective mass flux with an annual total of $5.0 \mathrm{Tg} \mathrm{N} \mathrm{yr}^{-1}$ for the year 2005. The resulting tropospheric ozone is typical: Northern Hemisphere (NH), 42.8 Dobson Units (DU); Southern Hemisphere (SH), 32.8 DU; STE flux, $590 \mathrm{Tg} \mathrm{yr}^{-1}$; surface deposition, $760 \mathrm{Tg} \mathrm{yr}^{-1}$; and, thus, net photochemical production, $170 \mathrm{Tg} \mathrm{yr}^{-1}$. Due to poor resolution in the upper stratosphere, the 40-layer meteorological fields (only version available at $1^{\circ} \times 1^{\circ}$ ) are anomalously high in the STE flux by about $15 \%$ compared to similar 60-layer meteorological fields (Hsu and Prather, 2009).

To simulate the Aura ozone instruments, we store the $\mathrm{CTM} \mathrm{O}_{3}$ in 3-D for each OMI swath, saving two datasets 30-min apart to interpolate the exact time for each pixel
( $\sim 63 \mathrm{~GB} \mathrm{yr}^{-1}$ in real $* 4$ format). We also save $65^{\circ} \mathrm{S}-65^{\circ} \mathrm{N}$ every two hours to match ozone sondes $\left(\sim 29 \mathrm{~GB} \mathrm{yr}^{-1}\right.$ in real*4 format). Therefore, we can generate individual observations.

A critical evaluation of the modelled ozone, particularly with regard to TFs is found with the ozone sonde measurements. In this test we restrict our comparison range from $35^{\circ} \mathrm{S}$ to $40^{\circ} \mathrm{N}$ where the $\mathrm{CTM}$ predicts the preponderance of TF, giving 638 World Ozone and Ultraviolet Radiation Data Centre (WOUDC) ozone sondes from 20 stations for 2005 (HKO et al., 2009). Ozone sondes have much finer vertical resolution than the CTM. Figure 1 shows four examples from Hong Kong (Fig. 1a), Ankara (Fig. 1b), and Huntsville (Fig. 1c, d). The CTM (blue solid line) agrees well with sonde (green dash line) in Fig. 1a, except for the overestimation in the boundary layer, due to the smoothing of the Hong Kong pollution plumes on our 100-km grid. Both CTM and sonde show fold structure near $251 \mathrm{hPa}$, but the CTM misses the fine structure reported by sonde at $140 \mathrm{hPa}$, leading to an offset of $50 \mathrm{ppb}$ (parts per billion, nanomoles per mole of air) in the profile. In Fig. 1b, CTM and sonde closely match with a $\mathrm{O}_{3}$ maximum at $400 \mathrm{hPa}$. In Fig. 1c, model and sonde are similar from the surface to $250 \mathrm{hPa}$ with a fold structure near $158 \mathrm{hPa}$, although of different magnitude. Comparison in Fig. 1d is the worst: CTM predicts an increase while sonde detects a decrease around $250 \mathrm{hPa}$; fold structure can be found in both from $100-158 \mathrm{hPa}$, but the patterns differ enormously. Overall, we grade $50 \%$ of these 638 comparisons as "A" (e.g., Fig. 1a, b), 30\% as "C" (e.g., Fig. 1c), and $20 \%$ as "F" (e.g., Fig. 1d).

The reported OMI profiles (de Haan and Veefkind, 2009) include 3-6 tropospheric layers, but only contain approximately one degree of freedom for the signal in the troposphere. Thus, TF detected by OMI could at best be detected as an enhancement somewhere in column, most likely in the troposphere, but not as a fold resolved by sonde or CTM. OMI profiles (magenta dot dash line) generally underestimate ozone values in the lower and middle troposphere, but overestimate them in upper troposphere and lower stratosphere (Fig. 1).

An objective criteria to identify TF is developed for the CTM based on subjective evaluations of the 638 sonde comparisons. TFs are defined in a boolean sense (Yes or No) from the vertical profile of $\mathrm{O}_{3}$ abundance: starting above $5 \mathrm{~km}$, once the $\mathrm{O}_{3}$ exceeds $80 \mathrm{ppb}$ and then within $3 \mathrm{~km}$ above decreases by $20 \mathrm{ppb}$ or more to a value less than $120 \mathrm{ppb}$. Note that TF detection depends in part on the vertical resolution of the CTM. Given this experiment, the uppermost tropospheric layer in fold must be at least $1 \mathrm{~km}$ thick. Also note that by these criteria, TFs can be caused by STE events and/or biomass burning. For example, Fig. 2 shows simulated global TCO maps for two "daily" (25-h periods) OMI swath observations, in which the $1^{\circ} \times 1^{\circ}$ pixels with a TF event are marked with "+". 


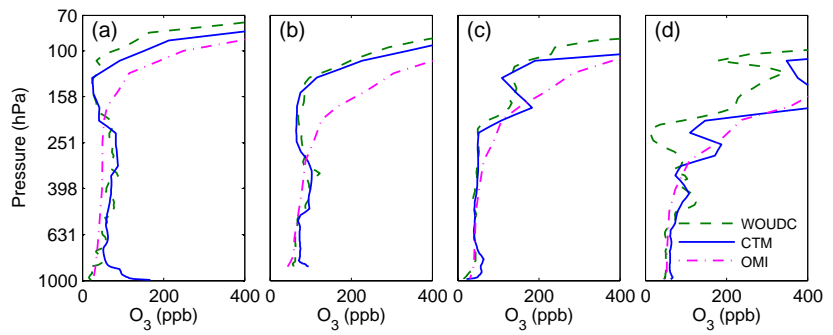

Fig. 1. $\mathrm{O}_{3}$ profiles (unit: ppb) from WOUDC (dashed), CTM (solid) and OMI (dash-dot) as a function of pressure (unit: hPa). (a) Hong Kong $\left(22.31^{\circ} \mathrm{N}, 114.17^{\circ} \mathrm{E}, \mathrm{STN} 344\right)$, China, 7 September 2005. (b) Ankara (39.97 $\left.\mathrm{N}, 32.86^{\circ} \mathrm{E}, \mathrm{STN} 348\right)$, Turkey, 17 August 2005. (c) Huntsville $\left(34.72^{\circ} \mathrm{N}, 86.64^{\circ} \mathrm{W}, \mathrm{STN} 418\right)$, AL, USA, 3 December 2005. (d) Huntsville for 5 March 2005.

\section{Satellite observation and tropospheric columns ozone}

The tropospheric column ozone (TCO) requires knowledge of the tropopause. The UCI CTM uses an artificial tracer emitted uniformly at the surface with uniform e-fold decay of 90 days (e90) to determine the boundary between troposphere and stratosphere. The e90 tracer allows for a dynamic allocation between stratospheric and tropospheric air masses instantaneously in 3-D for the purpose of the chemical model and diagnostics. It also provides a measure of the tropopause that is consistent with the traditional definition based on the 1-D temperature lapse rate and matches the sondes. Folds typically have tropospheric air masses overlying stratospheric air, and we identify the tropopause as the upper boundary of the uppermost model layer identified as tropospheric by its mean e 90 abundance. Thus, our TCO includes all $\mathrm{O}_{3}$ below this uppermost tropopause. The CTM TCO is shown in Fig. 2, beginning at 00:00:00 UTC for $25 \mathrm{~h}$ on 10 June and 3 December 2005. Note that anomalies of high TCO are often co-located with TF events.

The OMI instrument aboard the NASA's EOS Aura satellite has measured atmospheric composition from a sunsynchronous polar orbit since 9 August 2004 (Schoeberl et al., 2006; OMI Team, 2009). With a 2600-km swath width, OMI provides daily global coverage except for the points dropped due to OMI quality control and the gaps between swaths in tropics. Ziemke et al. (2006) derived global TCO from the OMI level 3 (L3, gridded/daily) and MLS level 2 (L2, orbit/swath) datasets, following the tropospheric ozone residual method (Fishman et al., 1990) by subtracting MLS stratospheric column from the OMI total column. The tropopause pressure was determined from NCEP re-analysis data. The resulting TCO cannot retain the heterogeneous spatial and temporal structures in OMI L2 data, which provide important clues to the existence of TFs. The use of OMI L3 data diffuses TCO features at high latitudes because different swath data (at least 90-min apart) are averaged. Further, in the overlap region necessary to achieve daily global

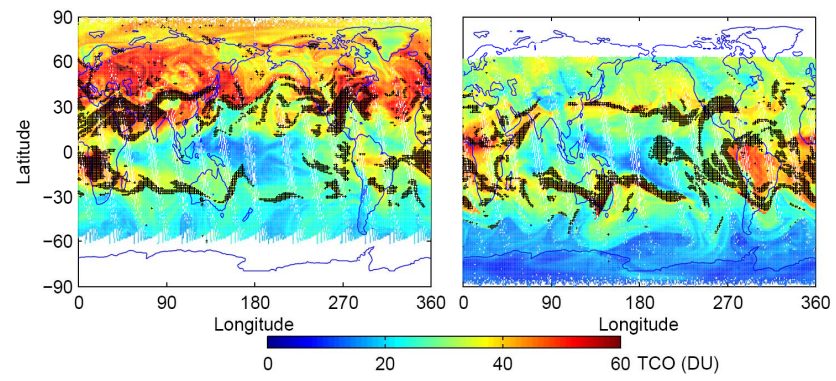

Fig. 2. CTM TCO (colour, unit: DU) co-located with TF events (black “+”) for 25-h periods beginning 00:00:00 UTC on 10 June (left) and 3 December (right) 2005.

maps, averaging is done over swaths 24-h apart, even in the tropics. The MLS L2 data (6-km cross-track width) (Livesey et al., 2007) must be extended across the OMI swath (2600$\mathrm{km}$ cross-track width), usually by interpolation with the next orbit, thus, some of the geographical variations in TCO are actually aliased from the variability in the OMI stratospheric column $\mathrm{O}_{3}$. Therefore, the method used by Ziemke et al. (2006) to calculate the TCO is not appropriate for the studies here concerning TFs.

In this study, we use the OMI L2 ozone profile dataset (OMO3PR V003) for the year 2005 (de Haan and Veefkind, 2009). The 18-layer ozone profile is based on the Optimal Estimation method (Rodgers, 2000) and derived from the signals of UV1 channel $(270-308.5 \mathrm{~nm})$ and part of the UV2 channel $(311.5-330 \mathrm{~nm})$, covering from the surface to $0.3 \mathrm{hPa}$. The Differential Optical Absorption Spectroscopy (DOAS) algorithm is implemented to retrieve the total ozone (Bhartia, 2002; Veefkind et al., 2006). Horizontal resolution of the OMI profiles (used here for TCO) is $13 \mathrm{~km} \times 48 \mathrm{~km}$ (along-track $\times$ cross-track) and that of the column (used here for total column ozone) is $13 \mathrm{~km} \times 24 \mathrm{~km}$ with a cross-track swath width of $2600 \mathrm{~km}$. Gaps between adjacent pixels in the raw OMI data disappear when accumulated onto the $1^{\circ} \times 1^{\circ}$ grid of the CTM. We select the same tropopause height as in the CTM simulation for each $1^{\circ} \times 1^{\circ}$ pixel and interpolate the OMI profile to get TCO. Note that this OMI L2 ozone profile dataset has not been evaluated in the troposphere and the tropospheric ozone is recommended to be used with extreme caution (OMI Team, 2009). The good agreement shown below between OMI and CTM TCO should, however, at least suggest that OMI retrieval derives reasonable TCO. Moreover, when compared with the independent Liu Xiong's OMI ozone product (Liu et al., 2010b, not shown), good agreement with the geographic TCO patterns is found. In addition, Liu et al. (2010a) validated the OMI profiles against MLS data in the stratosphere and implied that the OMI TCO can be correct. 

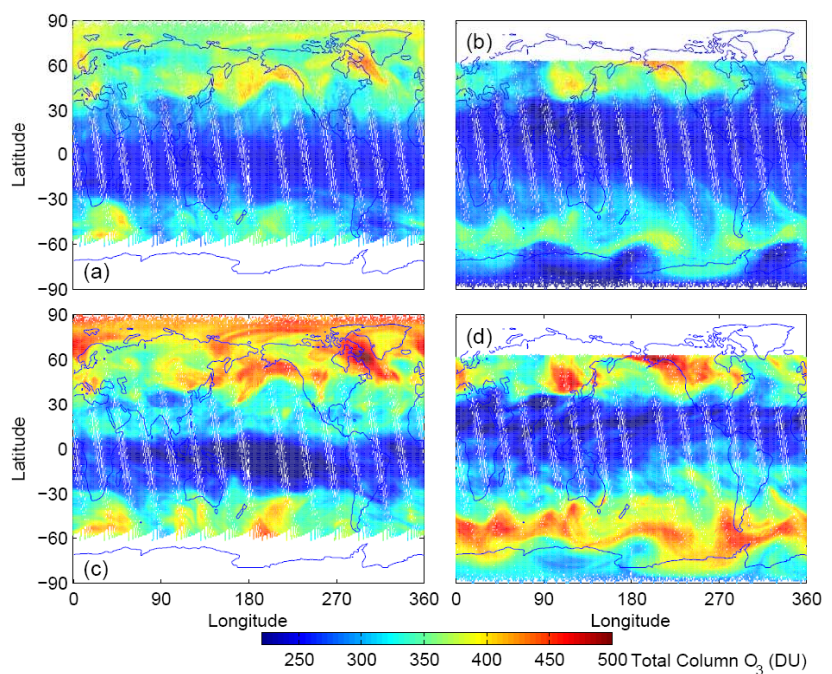

Fig. 3. Swath-by-swath comparison of total column $\mathrm{O}_{3}$ (unit: DU) from OMI (top) and CTM (bottom) for 10 June 2005 (left) and 3 December 2005 (right).

\subsection{Swath-by-swath comparison}

OMI L2 swath data allows us to study TFs on an hourly basis, which is important since they are not static over a day. Generally there is very good agreement between the modelled and measured ozone columns, both total and TCO. Importantly, the TCO anomalies are not correlated with total ozone anomalies which would be the case if we were aliasing upper tropospheric meteorologies (ridges and troughs) as STE intrusions. Thus, we find TFs drive variations in TCO but not in total column.

Analysis of the $25 \mathrm{~h}$ of swaths beginning at 00:00:00 UTC for 10 June are shown in Fig. 3a, c and Fig. 4a, c and for 3 December in Fig. 3b, d and Fig. 4b, d. The total column ozone for OMI is shown in Fig. 3a, b, while that for the CTM is in Fig. 3c, d. The UCI CTM successfully reproduces the patterns, but overestimates in most extra-tropical regions by about $15 \%$. We recognized this problem with the stratospheric circulation of the 40-layer ECMWF wind field (Hsu and Prather, 2009).

The TCO patterns (Fig. 4) are also quite similar, with smaller absolute error than for total ozone. In both OMI and CTM a band of high TCO ( 40 DU) at $30^{\circ} \mathrm{N}$ spreads from the Eastern Asia, across the Pacific and North America, to the central Atlantic. In December, the maximum regions to the east of Australia also appear in both. At $28^{\circ} \mathrm{S}$, however, OMI TCO has a narrow band of high TCO ( $\sim 45$ DU) across all longitudes, which seems unphysical and has no analog in the CTM. One apparent reason for this difference is the use of a fixed climatological profile for the a priori in the retrieval (de Haan and Veefkind, 2009). The $\mathrm{O}_{3}$-rich areas over tropical Africa and South America due to biomass burning in the CTM are missing in OMI, most likely because OMI is less
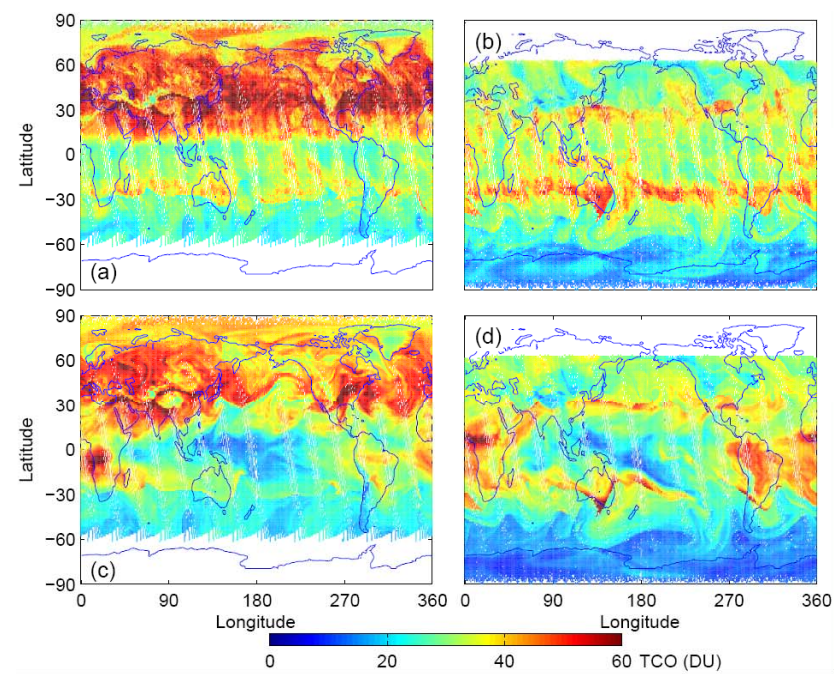

Fig. 4. Swath-by-swath comparison of tropospheric column $\mathrm{O}_{3}$ (TCO in DU) from OMI (top) and CTM (bottom) for 10 June 2005 (left) and 3 December 2005 (right).

sensitive to lower tropospheric $\mathrm{O}_{3}$ (Zhang et al., 2010). Likewise, OMI does not detect the very low TCO over equatorial western and central Pacific, where the low $\mathrm{O}_{3}$ abundances are predominantly near the surface.

\subsection{Bias and variability in the CTM tropospheric ozone}

Analysis of the time series of TCO for the months of June and December are shown in Figs. 5 and 6, respectively. The patterns of the monthly mean differences (CTM-OMI) show smooth large-scale features that change only little from month to month as shown in Figs. $5 \mathrm{c}$ and $6 \mathrm{c}$. For most of the daylit globe (56\% in June and 65\% in December), the differences are within \pm 5 DU. Larger, positive biases exist over Africa and South America. In June, the greatest differences are located at southern Africa, while in December large biases concentrate over central Africa, following the seasonality of biomass burning. Likewise, the differences over South America are more enhanced in December than in June. Significant low biases occur over western equatorial Pacific for both months related to the ozone loss in the marine boundary layer, where the CTM matches the typically low 5-15 ppb observed in the tropical Pacific (Davis et al., 1996; Crawford et al., 1997; Browell et al., 2003). In June, there is an extensive longitudinal extent of low CTM biases between $30^{\circ} \mathrm{N}$ and $40^{\circ} \mathrm{N}$ off the east coast of the continents, and this may be related to the similar problem of southern subtropical jet in December.

Consistency between the instantaneous CTM and OMI TCO is shown by the 2-D probability density function (PDF) (Figs. 5d and 6d), which represents two million instant, individual comparisons per month. The highest densities lie along the 1:1 line (black bold line) and errors are generally 

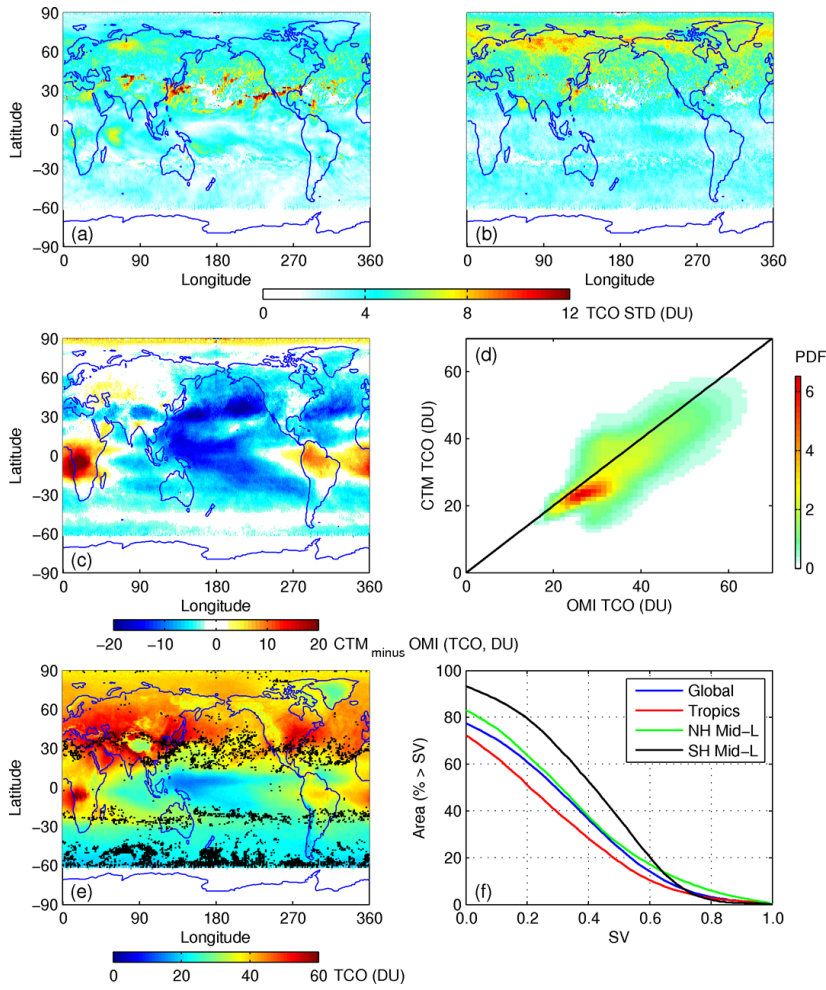

Fig. 5. For June 2005, the standard deviation $(\sigma)$ of TCO (in DU) for (a) CTM and (b) OMI (see text). (c) The bias (unit: DU) of the monthly mean TCO, CTM minus OMI. (d) 2-D probability distribution of $\mathrm{N} \times 10^{6}$ individual comparisons of OMI and CTM TCO. (e) monthly mean CTM TCO (unit: DU) with the locations of $S V \geq 0.70$ marked by black dots. (f) Cumulative probability distribution of SV (in (e) and (f), where $\mathrm{SV}_{\mathrm{TR}}$ and $\mathrm{SV}_{\mathrm{EX}}$ overlap, smaller values are presented).

symmetric in December, showing little overall bias. High latitude swaths overlay one another and result in oversampling, so our 2-D probability per DU ${ }^{2}$ includes all OMI-CTM coincidences in the month weighted by their pixel area and normalized to one observation time per pixel per day. It is renormalized to give a 2-D integral of 1.0. There is a low bias in the CTM for OMI ranges 20-35 DU in June, corresponding to tropical oceans, SH mid-latitudes and Greenland.

Removing the monthly mean TCO at each $1^{\circ} \times 1^{\circ}$ pixel, we can test the meteorologically driven variations. Note that the PDF of the global tropopause pressure (TPP) has a bimodal distribution with tropical and extra-tropical modes (see online discussion, http://www.atmos-chem-phys-discuss.net/10/14875/2010/ acpd-10-14875-2010-discussion.html). In regions containing both modes (usually about the subtropical jet), artificial TCO variations can be caused by the displacement between tropical tropopause and extra-tropical tropopause. Thus, we restrict our analysis on TCO variations to where the tropopause height is stable by applying a tropopause
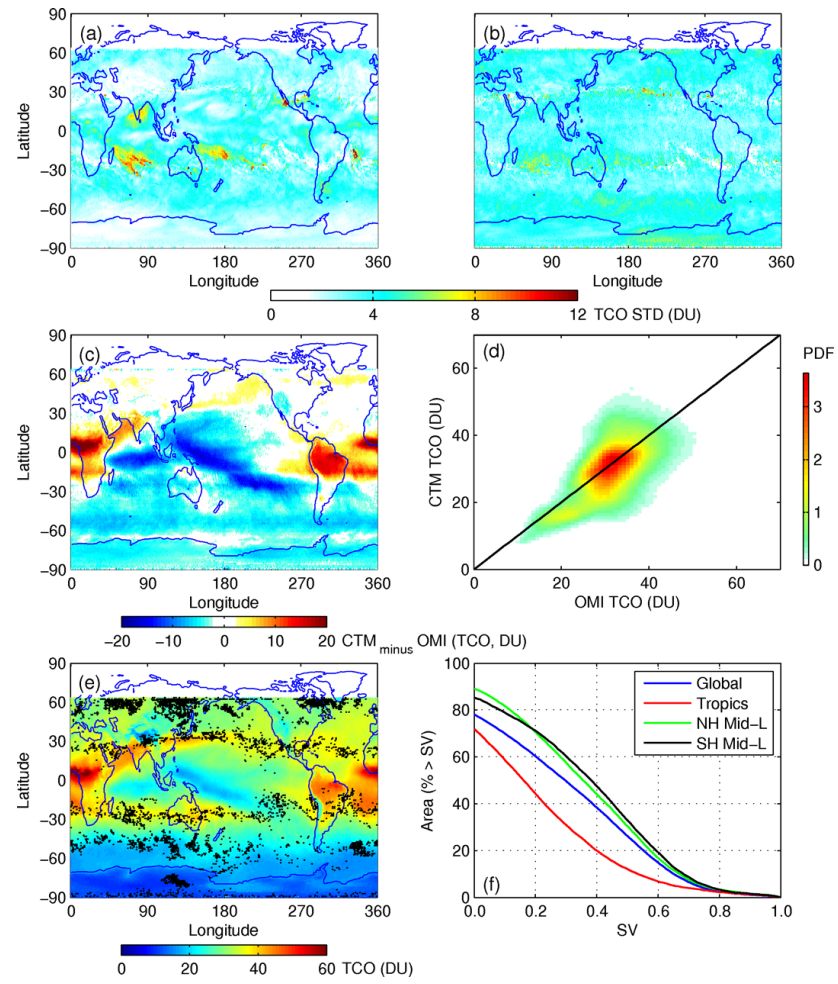

Fig. 6. For December 2005, same as Fig. 5.

filter. The filter is set up by fitting the PDF of global tropopause pressure with two normal distribution functions: $N_{\mathrm{TR}}\left(\mu_{\mathrm{TR}}, \sigma_{\mathrm{TR}}^{2}\right)$ for tropics (TR) and $N_{\mathrm{EX}}\left(\mu_{\mathrm{EX}}, \sigma_{\mathrm{EX}}^{2}\right)$ for extra-tropics (EX). The global TCO dataset is then divided into two subsets: $\mathrm{TCO}_{\mathrm{TR}}$ with $\mathrm{TPP}<\mu_{\mathrm{TR}}+\sigma_{\mathrm{TR}}$ and $\mathrm{TCO}_{\mathrm{EX}}$ with $\mathrm{TPP}>\mu_{\mathrm{EX}}-\sigma_{\mathrm{EX}}$. The data with $\mathrm{TPP} \in\left[\mu_{\mathrm{TR}}+\sigma_{\mathrm{TR}}, \mu_{\mathrm{EX}}-\sigma_{\mathrm{EX}}\right]$ are dropped. For June 2005, $\mu_{\mathrm{TR}}=91 \mathrm{hPa}, \sigma_{\mathrm{TR}}=11 \mathrm{hPa}, \mu_{\mathrm{EX}}=228 \mathrm{hPa}, \sigma_{\mathrm{EX}}=47 \mathrm{hPa}$ and, thus, data with TPP in the range of $102-181 \mathrm{hPa}$ are dropped, excluding $13 \%$ of the data. For December 2005, $\mu_{\mathrm{TR}}=85 \mathrm{hPa}, \sigma_{\mathrm{TR}}=15 \mathrm{hPa}, \mu_{\mathrm{EX}}=235 \mathrm{hPa}, \sigma_{\mathrm{EX}}=50 \mathrm{hPa}$ and data with TPP of $100-185 \mathrm{hPa}$ are excluded. The monthly standard deviation ( $\sigma$, STD) is then calculated for both subsets: the CTM matches OMI over much of the globe (Figs. 5a, b and 6a, b, where two subsets overlap, larger $\sigma$ is shown). Both generally agree on the locations of larger $\sigma$, primarily near the jet streams at $30^{\circ} \mathrm{S}$ and $30^{\circ} \mathrm{N}$. There are examples where the CTM overestimates $\sigma$ (e.g., north Pacific Ocean in June) and underestimates $\sigma$ (e.g., north Arabian Sea in June). The former are generally caused by a single, very large folding event that the CTM apparently overestimates. The larger $\sigma$ observed at high latitudes cannot be explained by the model.

To analyse how well we predict the synoptic variability of TCO, we note that if the residuals, $\mathrm{CTM}^{\prime}=\mathrm{CTM}-\overline{\mathrm{CTM}}$ and $\mathrm{OMI}^{\prime}=\mathrm{OMI}-\overline{\mathrm{OMI}}$, are uncorrelated, then the variance of the model residual minus the observational residual, 
$\overline{\left(\mathrm{CTM}^{\prime}-\mathrm{OMI}^{\prime}\right)^{2}}$, would be $\sigma_{\mathrm{CTM}}^{2}+\sigma_{\mathrm{OMI}}^{2}$. Thus, the simulated variance (SV) index defined as

$$
\mathrm{SV}=1-\frac{\overline{\left(\mathrm{CTM}^{\prime}-\mathrm{OMI}^{\prime}\right)^{2}}}{\sigma_{\mathrm{CTM}}^{2}+\sigma_{\mathrm{OMI}}^{2}}
$$

is a measure of the fraction of variance that is accurately simulated. The average and $\sigma$ are weighted by the pixel area and observation frequency as above. By definition, SV ranges from negative (when $\mathrm{CTM}^{\prime}$ and $\mathrm{OMI}^{\prime}$ are anti-correlated) to +1 (when $\mathrm{CTM}^{\prime}$ and $\mathrm{OMI}^{\prime}$ are identical). The SV is calculated separately for both tropical and extra-tropical subsets. The mean $\mathrm{SV}_{\mathrm{TR}}$ and $\mathrm{SV}_{\mathrm{EX}}$ are 0.29 and 0.34 for June, and 0.21 and 0.39 for December. In the following analysis where $\mathrm{SV}_{\mathrm{TR}}$ and $\mathrm{SV}_{\mathrm{EX}}$ overlap, the smaller values, indicating less accurate predictability, are presented. Figures $5 \mathrm{e}$ and $6 \mathrm{e}$ show the geographic patterns of CTM monthly mean TCO, where those locations with SV greater than 0.70 are marked by black dots. Note that in areas where the CTM matches the high frequency variability of OMI, $\sigma$ is also large, particularly along the subtropical jet streams near $30^{\circ} \mathrm{S}$ and $30^{\circ} \mathrm{N}$ (Figs. 5a, b and 6a, b).

Figures $5 f$ and $6 f$ present the cumulative distribution function (CDF) of the index SV weighted by area (i.e., the percentage of area whose $\mathrm{SV}$ is greater than or equal to the value on the X-axis) for the globe (blue line), tropics $\left(25^{\circ} \mathrm{S}-25^{\circ} \mathrm{N}\right.$, red line), $\mathrm{NH}$ mid-latitudes $\left(25^{\circ} \mathrm{N}-50^{\circ} \mathrm{N}\right.$, green line), and $\mathrm{SH}$ mid-latitudes $\left(50^{\circ} \mathrm{S}-25^{\circ} \mathrm{S}\right.$, black line). Independent of seasons, the $\mathrm{SV}$ is best in $\mathrm{SH}$ mid-latitudes, moderate in $\mathrm{NH}$ mid-latitudes, and worst in the tropics.

\section{TF anomalies vs. STE ozone flux}

We expect regions with TF to be associated with STE $\mathrm{O}_{3}$ flux as the folds are sheared and mixed with tropospheric air. The TF frequency is calculated from the 2-h global $\mathrm{O}_{3}$ fields from the CTM (Fig. 7). Two latitude bands with a high frequency of TF are located near the subtropical jet stream in each hemisphere. The high frequency regions over equatorial Africa and South America are actually aliased from biomass burning plumes, as our TF criteria detect biomass burning plumes rising above $5 \mathrm{~km}$ as TF events. The $\mathrm{STE} \mathrm{O}_{3}$ flux is diagnosed by following the dilution of stratospheric $\mathrm{O}_{3}$ (Hsu et al., 2005; Hsu and Prather, 2009), and for these fluxes we use a chemical tropopause of $120 \mathrm{ppb}$ of $\mathrm{O}_{3}$. Note that this method directly calculates the $\mathrm{O}_{3}$ flux across a surface every time step and may not agree in magnitude, timing nor location with other methods using the residual circulation (e.g., Gettelman et al., 1997) or surrogates, such as potential vorticity (e.g., Olsen et al., 2003). Since the $1^{\circ} \times 1^{\circ}$ 60 -layer meteorology field is not available and the STE flux from $1^{\circ} \times 1^{\circ}$ field is only slightly different from that derived from T42 field with the same vertical resolution, the STE flux is calculated using meteorology at T42 horizontal resolution with 60 vertical layers. This 60 -layer field is basically the

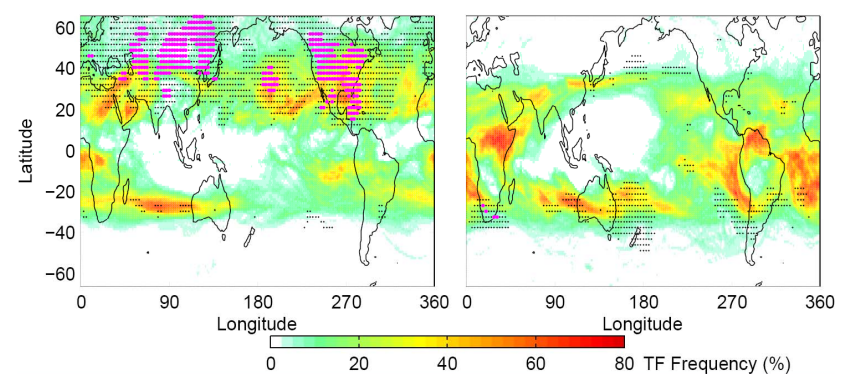

Fig. 7. TF frequency (colour, unit: \%) for June (left) and December (right) 2005 with $\mathrm{STE} \mathrm{O}_{3}$ fluxes (unit: $\mathrm{g} \mathrm{m}^{-2} \mathrm{yr}^{-1}$ ) shown by black dots $(2 \leq \mathrm{STE}<4)$ and magenta dots $(\mathrm{STE} \geq 4)$. The TF frequency is calculated by dividing the number of times that a TF occurs (i.e., sampled every $2 \mathrm{~h}$ ) by the total times sampled.

same EC meteorology as the $1^{\circ} \times 1^{\circ} 40$-layer, but has much better stratospheric circulation and STE $\mathrm{O}_{3}$ flux. The STE $\mathrm{O}_{3}$ flux is larger in $\mathrm{NH}$ than in $\mathrm{SH}$, and in the summer of each hemisphere. The TF frequency and STE $\mathrm{O}_{3}$ flux are better coincident in $\mathrm{SH}$ than in $\mathrm{NH}$, probably due to the more zonal structure in the $\mathrm{SH}$, as large scale planetary waves may drive the location of final STE mixing away from the jet in the NH. From June through August, large NH STE flux occurs over almost all of the Asian and North American continents and is not associated with TF. Over Asia the large STE region expands beyond $60^{\circ} \mathrm{N}$, while high TF frequency area only reaches $40^{\circ} \mathrm{N}$. This STE $\mathrm{O}_{3}$ flux is associated with deep convection (Baray et al., 1999; De Bellevue et al., 2006). Convection over summer continents extends into the lower stratosphere, dragging $\mathrm{O}_{3}$-rich air into the troposphere. In the CTM approximately $5 \%$ of the summertime continental convection reaches $\mathrm{O}_{3}$ levels above $120 \mathrm{ppb}$. Additionally, the summer monsoon might contribute to this large STE flux, but the latitudinal extent is too large to be attributed to the monsoon alone.

\section{Conclusions}

Comparing the CTM profiles with WOUDC ozone sondes reveals that the model matches sonde measurements and is capable of locating and resolving tropopause fold events. In the CTM, high ozone anomalies in the tropospheric column are correlated with TF events and occur most frequently near the subtropical jet streams, which is consistent with previous studies (Baray et al., 2000; Traub and Lelieveld, 2003). Over the whole year, the TF's frequency is $12 \%$ in the $\mathrm{NH}$ and $9 \%$ in the $\mathrm{SH}$, with $13 \%$ and $11 \%$ of the area in $\mathrm{NH}$ and $\mathrm{SH}$ covered by TFs, in parallel with the inter-hemispheric differences in $\mathrm{STE} \mathrm{O}_{3}$ flux of $320 \mathrm{Tg}$ and $270 \mathrm{Tg}$, respectively.

The real-time tropospheric and total ozone columns measured by OMI are simulated by the UCI CTM for year 2005 . The modelled ozone columns show very good agreement with coincident high frequency OMI observations, both in 
terms of the geographical patterns and variability. Model results are generally better in extra-tropics than in tropics, in part, because of the problems with the CTM's tropical stratospheric meteorology, in part, because OMI is not sensitive to $\mathrm{O}_{3}$ from biomass burning. Except for biomass burning regions in Africa and South America and for certain regions over oceans, the monthly mean TCO falls within \pm 5 DU range of OMI values. Further analysis shows that the highfrequency variations in TCO observed by OMI are very well matched outside the tropics by the UCI CTM using the high resolution ECMWF pieced-forcast fields.

Having demonstrated the link between OMI anomalies in the tropospheric column ozone (TCO) and tropopause folds, we seek to extend it to the stratosphere-troposphere exchange (STE) ozone flux. The STE flux in the vicinity of the subtropical jets can possibly be measured with TCO anomalies, but the large regions over the summer continents in the $\mathrm{NH}$ occur through deep convection and are less apparent in the OMI ozone columns.

Acknowledgements. Thanks to the Aura science team and PIs for their support in our analysis, specifically the ozone instruments: HIRDLS, MLS, OMI, TES. This work is supported by NASA grant (NNX08AR25G) to UCI.

Edited by: P. Jöckel

\section{References}

Appenzeller, C., Holton, J. R., and Rosenlof, K. H.: Seasonal variation of mass transport across the tropopause, J. Geophys. Res., 101, 15071-15078, doi:10.1029/96JD00821, 1996.

Baray, J.-L., Ancellet, G., Randriambelo, T., and Baldy, S.: Tropical cyclone Marlene and stratosphere-troposphere exchange, J. Geophys. Res., 104, 13953-13970, doi:10.1029/1999JD900028, 1999.

Baray, J.-L., Daniel, V., Ancellet, G., and Legras, B.: Planetaryscale tropopause folds in the southern subtropics, Geophys. Res. Lett., 27, 353-356, doi:10.1029/1999GL010788, 2000.

Beekmann, M., Ancellet, G., Blonsky, S., Muer, D. D., Ebel, A., Elbern, H., Hendricks, J., Kowol, J., Mancier, C., Sladkovic, R., Smit, H. G. J., Speth, P., Trickl, T., and Haver, P. V.: Regional and Global Tropopause Fold Occurrence and Related Ozone Flux Across the Tropopause, J. Atmos. Chem., 28, 29-44, doi: 10.1023/A:1005897314623, 1997.

Bhartia, P. K.: OMI Algorithm Theoretical Basis Document, OMI Ozone Products, http://eospso.gsfc.nasa.gov/eos_homepage/for scientists/atbd/docs/OMI/ATBD-OMI-02.pdf, 2002.

Browell, E. V., Fenn, M. A., Butler, C. F., Grant, W. B., Brackett, V. G., Hair, J. W., Avery, M. A., Newell, R. E., Hu, Y., Fuelberg, H. E., Jacob, D. J., Anderson, B. E., Atlas, E. L., Blake, D. R., Brune, W. H., Dibb, J. E., Fried, A., Heikes, B. G., Sachse, G. W., Sandholm, S. T., Singh, H. B., Talbot, R. W., Vay, S. A., Weber, R. J., and Bartlett, K. B.: Large-scale ozone and aerosol distributions, air mass characteristics, and ozone fluxes over the western Pacific Ocean in late winter/early spring, J. Geophys. Res., 108, 8805, doi:10.1029/2002JD003290, 2003.
Carver, G., Brown, P., and Wild, O.: The ASAD atmospheric chemistry integration package and chemical reaction database, Comput. Phys. Commun., 105, 197-215, 1997.

Crawford, J., Davis, D., Chen, G., Bradshaw, J., Sandholm, S., Kondo, Y., Liu, S., Browell, E., Gregory, G., Anderson, B., Sachse, G., Collins, J., Barrick, J., Blake, D., Talbot, R., and Singh, H.: An assessment of ozone photochemistry in the extratropical western North Pacific: Impact of continental outflow during the late winter/early spring, J. Geophys. Res., 102, 2846928487, 1997.

Crutzen, P.: Discussion of chemistry of some minor constituents in stratosphere and troposphere, Pure Appl. Geophys., 106, 13851399, 1973.

Danielsen, E. F.: Stratospheric-tropospheric exchange based on radioactivity, ozone and potential vorticity, J. Atmos. Sci., 25, 502518, 1968.

Davis, D. D., Crawford, J., Chen, G., Chameides, W., Liu, S., Bradshaw, J., Sandholm, S., Sachse, G., Gregory, G., Anderson, B., Barrick, J., Bachmeier, A., Collins, J., Browell, E., Blake, D., Rowland, S., Kondo, Y., Singh, H., Talbot, R., Heikes, B., Merrill, J., Rodriguez, J., and Newell, R. E.: Assessment of ozone photochemistry in the western North Pacific as inferred from PEM-West A observations during the fall 1991, J. Geophys. Res., 101, 2111-2134, 1996.

De Bellevue, J. L., Réchou, A., Baray, J. L., Ancellet, G., and Diab, R. D.: Signatures of stratosphere to troposphere transport near deep convective events in the southern subtropics, J. Geophys. Res., 111, D24107, doi:10.1029/2005JD006947, 2006.

de Haan, J. F. and Veefkind, J. P.: OMO3PR Readme, http://disc.sci.gsfc.nasa.gov/Aura/data-holdings/OMI/ documents/v003/OMO3PRO_README.html, 2009.

Fishman, J., Watson, C. E., Larsen, J. C., and Logan, J. A.: Distribution of Tropospheric Ozone Determined From Satellite Data, J. Geophys. Res., 95, 3599-3617, 1990.

Gettelman, A., Holton, J., and Rosenlof, K.: Mass fluxes of $\mathrm{O}_{3}$, $\mathrm{CH}_{4}, \mathrm{~N}_{2} \mathrm{O}$ and $\mathrm{CF} 2 \mathrm{Cl} 2$ in the lower stratosphere calculated from observational data, J. Geophys. Res., 102, 19149-19159, doi:10. 1029/97JD01014, 1997.

HKO, INPE, JMA, KNMI, MDI, MeteoSwiss, MMS, NASAWFF, NASDA, NOAA-CMDL, SAWS, TSMS, U_LaReunion, U_Rome-CRPSM, and UAH: World Ozone and Ultraviolet Radiation Data Centre (WOUDC) [Data], http://www.woudc.org, retrieved 30 July 2009.

Holton, J. R., Haynes, P. H., McIntyre, M. E., Douglass, A. R., Rood, R. B., and Pfister, L.: Stratosphere-troposphere Exchange, Rev. Geophys., 33, 403-439, 1995.

Hoor, P., Borken-Kleefeld, J., Caro, D., Dessens, O., Endresen, O., Gauss, M., Grewe, V., Hauglustaine, D., Isaksen, I. S. A., Jöckel, P., Lelieveld, J., Myhre, G., Meijer, E., Olivie, D., Prather, M., Schnadt Poberaj, C., Shine, K. P., Staehelin, J., Tang, Q., van Aardenne, J., van Velthoven, P., and Sausen, R.: The impact of traffic emissions on atmospheric ozone and $\mathrm{OH}$ : results from QUANTIFY, Atmos. Chem. Phys., 9, 3113-3136, doi:10.5194/acp-9-3113-2009, 2009.

Hsu, J. and Prather, M. J.: Stratospheric variability and tropospheric ozone, J. Geophys. Res., 114, D06102, doi:10.1029/ 2008JD010942, 2009.

Hsu, J., Prather, M. J., and Wild, O.: Diagnosing the stratosphereto-troposphere flux of ozone in a chemistry transport model, J. 
Geophys. Res., 110, D19305, doi:10.1029/2005JD006045, 2005.

Jaeger, E. B. and Sprenger, M.: Vorticity, deformation and divergence signals associated with stratosphere-troposphere exchange, Q. J. Roy. Meteorol. Soc., 135, 1684-1696, doi:10.1002/ qj. 482, 2009.

Lamarque, J.-F. and Hess, P. G.: Cross-tropopause Mass Exchange and Potential Vorticity Budget in a Simulated Tropopause Folding, J. Atmos. Sci., 51, 2246-2269, 1994.

Levy, H.: Photochemistry of the lower troposphere, Planet. Space. Sci., 20, 919-935, 1972.

Liu, X., Bhartia, P. K., Chance, K., Froidevaux, L., Spurr, R. J. D., and Kurosu, T. P.: Validation of Ozone Monitoring Instrument (OMI) ozone profiles and stratospheric ozone columns with Microwave Limb Sounder (MLS) measurements, Atmos. Chem. Phys., 10, 2539-2549, doi:10.5194/acp-10-2539-2010, 2010a.

Liu, X., Bhartia, P. K., Chance, K., Spurr, R. J. D., and Kurosu, T. P.: Ozone profile retrievals from the Ozone Monitoring Instrument, Atmos. Chem. Phys., 10, 2521-2537, doi:10.5194/acp-10-25212010, 2010b.

Livesey, N. J., Read, W. G., Lambert, A., Cofield, R. E., Cuddy, D. T., Froidevaux, L., Fuller, R. A., Jarnot, R. F., Jiang, J. H., Jiang, Y. B., Knosp, B. W., Kovalenko, L. J., Pickett, H. M., Pumphrey, H. C., Santee, M. L., Schwartz, M. J., Stek, P. C., Wagner, P. A., Waters, J. W., and Wu, D. L.: EOS MLS Version 2.2 Level 2 data quality and description document, Tech. Rep. D-33509, JPL, Jet Propulsion Laboratory California Institute of Technology Pasadena, California, 91109-8099, 2007.

Olsen, M. A., Douglass, A. R., and Schoeberl, M. R.: A comparison of Northern and Southern Hemisphere cross-tropopause ozone flux, Geophys. Res. Lett., 30, 1412, doi:10.1029/ 2002GL016538, 2003.

OMI Team: Ozone Monitoring Instrument (OMI) Data User's Guide, OMI-DUG-3.0, http://disc.sci.gsfc.nasa.gov/Aura/ additional/documentation/README.OMI_DUG.pdf, 2009.

Rodgers, C. D.: Inverse methods for atmospheric sounding: Theory and practice, World Scientific Publishing Co., 2000.

Schoeberl, M. R., Douglass, A. R., Hilsenrath, E., Bhartia, P. K., Beer, R., Waters, J. W., Gunson, M. R., Froidevaux, L., Gille, J. C., Barnett, J. J., Levelt, P. F., and DeCola, P.: Overview of the EOS Aura mission, IEEE T. Geosci. Remote, 44, 1066-1074, doi:10.1109/TGRS.2005.861950, 2006
Sprenger, M., Maspoli, M. C., and Wernli, H.: Tropopause folds and cross-tropopause exchange: A global investigation based upon ECMWF analyses for the time period March 2000 to February 2001, J. Geophys. Res., 108, 8518, doi:10.1029/2002JD002587, 2003.

Stohl, A., Bonasoni, P., Cristofanelli, P., Collins, W., Feichter, J., Frank, A., Forster, C., Gerasopoulos, E., Gäggeler, H., James, P. Kentarchos, T., Kromp-Kolb, H., Krüger, B., Land, C., Meloen, J., Papayannis, A., Priller, A., Seibert, P., Sprenger, M., Roelofs, G. J., Scheel, H. E., Schnabel, C., Siegmund, P., Tobler, L., Trickl, T., Wernli, H., Wirth, V., Zanis, P., and Zerefos, C.: Stratosphere-troposphere exchange: A review, and what we have learned from STACCATO, J. Geophys. Res., 108, 8516, doi: 10.1029/2002JD002490, 2003.

Traub, M. and Lelieveld, J.: Cross-tropopause transport over the eastern Mediterranean, J. Geophys. Res., 108, 4712, doi:10. 1029/2003JD003754, 2003.

Veefkind, J. P., de Haan, J. F., Brinksma, E. J., Kroon, M., and Levelt, P. F.: Total Ozone from the Ozone Monitoring Instrument (OMI) Using the DOAS Technique, IEEE T. Geosci. Remote, 44, 1239-1244, doi:10.1109/TGRS.2006.871204, 2006.

Wild, O., Sundet, J., Prather, M., Isaksen, I., Akimoto, H., Browell, E., and Oltmans, S.: Chemical transport model ozone simulations for spring 2001 over the western Pacific: Comparisons with TRACE-P lidar, ozonesondes, and Total Ozone Mapping Spectrometer columns, J. Geophys. Res., 108, 8826, doi: 10.1029/2002JD003283, 2003.

Zhang, L., Jacob, D. J., Liu, X., Logan, J. A., Chance, K., Eldering, A., and Bojkov, B. R.: Intercomparison methods for satellite measurements of atmospheric composition: application to tropospheric ozone from TES and OMI, Atmos. Chem. Phys., 10, 4725-4739, doi:10.5194/acp-10-4725-2010, 2010.

Ziemke, J. R., Chandra, S., Duncan, B. N., Froidevaux, L., Bhartia, P. K., Levelt, P. F., and Waters, J. W.: Tropospheric ozone determined from Aura OMI and MLS: Evaluation of measurements and comparison with the Global Modeling Initiatives Chemical Transport Model, J. Geophys. Res., 111, D19303, doi: 10.1029/2006JD007089, 2006. 